\title{
Factor XI Deficiency: First Case Described in Algeria
}

Abdessamed Arabi ${ }^{*}$, Mohamed Chekkal, Leila Charef, Samira Bouchama, Sihem Mehded, Mohamed Brahimi, Nabil Yafour and Mohamed-Amine Bekadja

Haematology and Cell Therapy Unit, Etablissement Hospitalier et Universitaire 1er Novembre 1954 Oran, Algeria

*Corresponding author: Abdessamed Arabi, Haematology and Cell Therapy Unit, Etablissement Hospitalier et Universitaire 1er Novembre 1954 Oran, Algeria, Tel: 2134142163; E-mail: abdessamed.arabi@gmail.com

Received date: Jul 15, 2015, Accepted date: Aug 18, 2015, Publication date: Aug 22, 2015

Copyright: (c) 2015 Arabi A, et al. This is an open-access article distributed under the terms of the Creative Commons Attribution License, which permits unrestricted use, distribution, and reproduction in any medium, provided the original author and source are credited.

\begin{abstract}
Factor XI deficiencies are very rare and the first case was registered among Ashkenazy Jews with two types of characteristic gene mutation. Today 152 mutations have been identified even among non-Jewish population.

The present study reports the deficiency identified in a young Arabic girl living in West Algeria; gene seqensage with type II mutation was noticed in Ashkenazy Jews frequently. The present study concludes that it is happening either coincidentally or due to the constant migration history of this region.
\end{abstract}

Keywords: Factor XI deficiencies; Ashkenazy Jews; Arabic young girl living in West Algeria -type II mutation

\section{Introduction}

Factor XI (FXI) deficiency was described for the first time in a Jewish family in USA and was called (haemophilia C). It is distinguished from hemophilia A and B by its appearance in both the sex and the absence of spontaneous bleeding [1]

FXI deficiency is particularly common among Ashkenazi Jews; it is one of the most common genetic disorders in this population with heterozygous frequency of $8 \%[2]$.

FXI deficiency is not known among the non-Jewish population, as is the case for Algeria. This bleeding disorder is probably under diagnosed as the patients with severe or partial FXI deficiency do not suffer from spontaneous bleeding but may do so only after haemostatic challenge that generally occur due to surgery or trauma. Women in general are exposed to bleeding every month during their menstruations and child birth. Moreover, there is often a poor correlation between bleeding and the baseline FXI clotting activity [3].

Inherited FXI deficiency has now been described in a wide variety of population groups but remains most common in Ashkenazy Jews. In this group, it is estimated that one in eight individuals is heterozygous and one in 190 are homozygous for FXI gene mutations $[4,5]$.

Most cases of FXI deficiency in Ashkenazi Jews are caused by two distinct mutations, each accounting for $40-50 \%$ of abnormal alleles. These are Glu117Strop, also referred as type II mutation and Phe283Leu, the type III mutation.

Type III mutation occurs almost exclusively among Ashkenazy Jews, the type II mutation is found mostly among Iraqi Jews and Arabs, suggesting an earlier ancestral origin [6,7]. Phe283Leu results in impaired dimer formation producing a quantitative deficiency [8]. The present study discusses about XI deficiency discovered in a little girl born in Mostaganem of Western Algerian city.

\section{Materials and Methods}

B.K was born in 1997 in Mostaganem out of a consanguineous marriage; she was referred to the department of hematology in 2008 for exploration of aPTT discovered during preoperative assessment for tonsillectomy.

Clinical examination was normal, but medical history was marked by frequent epitasis, and reported hematomas after intramuscular injections and ecchymosis. Menarche was identified when the patient was 11 years old with a severe bleeding.

She is the youngest of 3 brothers and 3 sisters and none in the family had any bleeding symptom and the other siblings have refused to be included in screening.

Blood samples were obtained from the patient and her parents after informed consent. Prothrombin time, aPTT, fibrinogen concentration, factor VIII, factor IX and factor XI activities and vonWillebr and factor (ristocetinco-factor activity and antigen) were measured with standard assays using the BCS analyzer (Dade Behring, Marburg, Germany) and the Vidasanalyser (BioMerieux, Marcy l'Etoile, France).

Genomic DNA from the proband, the father and the mother were purified from leucocytes as per the standard protocols. The F11gene was analyzed by direct sequencing. Coagulation results for the Propositus are shown in Table 1. Values of FXI of the parents were as follows: Father: $40 \%$ and Mother: $30 \%$. The gene sequencing analysis of Factor XI gene are shown in Table 2.

\begin{tabular}{|l|l|}
\hline Coagulation tests & Result \\
\hline aPTT & $74 \mathrm{sec}(\mathrm{T}=31)$ \\
\hline Prothrombin time & $13 \mathrm{sec}(\mathrm{T}=12)$ \\
\hline Prothrombin Ratio & $82 \%$ \\
\hline Fibrinogen & $2,50 \mathrm{~g} / \mathrm{L}(\mathrm{N}=2-4)$ \\
\hline Factor VIII & $90 \%(\mathrm{~N}=60-150 \%)$ \\
\hline Factor IX & $100 \%(\mathrm{~N}=60-120 \%)$ \\
\hline
\end{tabular}




\begin{tabular}{|l|l|}
\hline Circulating anticoagulants antibodies & Negative \\
\hline VWF :Ag & $85 \%(\mathrm{~N}=50-150 \%)$ \\
\hline VWF:Rco & $55 \%(\mathrm{~N}=50-150 \%)$ \\
\hline Factor $\mathrm{XI}$ & $10 \%(\mathrm{~N}=70-120 \%)$ \\
\hline
\end{tabular}

Table 1: Results of coagulation tests for the propositus.

\begin{tabular}{|l|l|}
\hline Subject & Result \\
\hline Propositus & Mutation p.Glu 117 stop homozygous (Type II) \\
\hline Father & Mutation p.Glu 117 stop heterozygous (Type II) \\
\hline Mother & Mutation p.Glu 117 stop heterozygous (Type II) \\
\hline
\end{tabular}

Table 2: The gene sequencing analysis of Factor XI genes.

\section{Discussion}

According to a rigorous review of the existing literature, (The author must be able to show some evidence that this first of its kind in the country). The present case of FXI deficit reported in Algeria is first of its kind and it is incomprehensible because this country's history is marked with significant episodes of migration of Turkish, Spanish and French people. Sephardic Jews have settled and lived for long time in Algeria after the Catholicon's conquest of Granada in 1492 and consanguineous marriages have become prevalent ever since that time.

However, FXI deficiency is a rare bleeding disorder that occurs one in a million [9] and that must be the reason why there is no data available on these type of incidents in the entire country.

It has been reported that FXI deficiency is associated with a variable injury-related bleeding diathesis among patients with severe deficiency and partial deficiency [10]. Bleeding is associated with trauma or surgery, and spontaneous bleeding is not typical.

Which is the case in our patient; despite a severe deficiency, hemorrhagic signs remained moderate. Several studies have been conducted to evaluate to determine the reasons for this bleeding tendency. Neither plasma levels of FXI coagulant activity (FXI:C) nor FXI antigen (FXI:Ag) were associated with these bleeding . However, bleeding is significantly associated with homozygous type II mutations and compound type II-type III mutations in FXI, resulting in severe deficiency in FXI and low plasma levels. Bleeding is also increased when plasma levels of the vonWillebrand factor (VWF) are lower than normal level [11].

Over $96 \%$ of FXI deficiency have occurred due to two of four common mutations found in Ashkenazi Jews, namely type II (a nonsense mutation in exon 5) and type III (amissense mutation in exon 9) [12]. Manaka et al. identified two other mutation cases among non-Jewish population. In case 1, a $T$ to $G$ transition in exon 12 resulted in the substitution of Phe-442 by Val (FXLF442V). In case 2, a $\mathrm{C}$ to $\mathrm{A}$ transition in exon 5 resulted in the substitution of Cys-128 by a nonsense codon (FXI-C128X) [13].

Alhaq et al. described another mutation incident among non-Jewish population, which depicted the TGG to TGC transversion in codon 228 of exon 7 (FXI-W228C). This missense mutation results in a Trp to Cys substitution within the third appledomain of FXI [14], nine other mutations have been identified in France and seven families from the west of France were affected with mutations of [15]: Q88X het (exon 4), Q88X hom (exon 4), T575M het (exon 15), nt 137 ins G (exon 3), R210X het (exon7), G336R het (exon 10), G581X hom (exon 15), G581X het (exon15) and G350A het (exon 10).

Curiously, all these mutations have not clinical consequences. 152 mutations till date of FXI gene have been reported with four cases exhibiting founder effects in specific populations; Glu117stop in Ashkenazi and Iraqui Jews and Arabs, Phe283Leu in Ashkenazi Jews, Cys38Arg in Basques, and Cys128stop in the United Kindgom have been documented. Severe FXI deficiency does not confer protection against acute myocardial infarction, but it is associated with reduced incidences of ischemic stroke. Inhibitors to FXI developed only among one-third of the cases reported with a very severe FXI deficiency, following exposure to blood products .Therapy for prevention of bleeding during surgery for patients with severe FXI deficiency consists of plasma, factor XI concentrates, fibrin glue and antifibrinolytic agents. Patients with an inhibitor to FXI, recombinant factor VIIa is also useful [16].

Concerning Algeria, the authors of this study consider this case report as first of its kind to get published. They are not concluding this as the last case either. They however agree that the prospect about the frequency of FXI deficiency and types of mutations associated with it in future must be observed carefully. They are seriously discussing this case with the researchers of anthropology centre for more information related to the history of migration in Algeria.

\section{References}

1. Rosenthal RL, Dreskin OH, Rosenthal N (1953) New haemophilia-like disease caused by deficiency of a third plasma thromboplastin factor. Proc Soc Exp Biol Med 82 : 171-174.

2. Seligsohn U (1993) Factor XI deficiency. Thromb Haemost 70: 68-71.

3. Bolton-Maggs PH, Patterson DA, Wensley RT, Tuddenham EG (1995) Definition of the bleeding tendency in factor XI-deficient kindreds : a clinical and laboratory study. Thromb Haemost 73:194-202.

4. Asakai R, Davie EW, Chung DW (1987) Organization of the gene for human factor XI. Biochemistry 26: 7221-7228.

5. Seligsohn U (1978) High gene frequency of factor XI (PTA) deficiency in Ashkenazy Jews. Blood 51:1223-1228 .

6. Goldstein DB, Reich DE, Bradman N, Usher S, Seligsohn U, et al. (1999) Age estimates of two common mutations causing factor XI deficiency : Recent genetic drift is not necessary for elevated disease incidence among Ashkenazi Jews. Am J Hum Genet 64: 1071-1075.

7. Peretz H, Mulai A, Usher S, Zivelin A, Segal A, Weisman Z, et al. (1998) The two common mutations causing factor XI deficiency in Jews stem from distinct founders : one of ancient Middle Eastern origin and another of more recent European origin. Blood 90: 2654-2659.

8. Meijers JC, Davie EW, ChungDW (1992) Expression of human blood coagulation factor XI: characterization of the defect in factor XI type III deficiency. Blood 79: 1435-1440.

9. Saunders RE, O'Connell NM, Lee CA, Perry DJ, Perkins SJ (2005) Factor XI Deficiency Database: An Interactive Web database of Mutations, Phenotypes, ans Strucural Analysis Tools. Hum Mutat 26:192-198.

10. Bolton-Maggs PH, Patterson DA, Wensley RT, Tuddenham EG (1995) Definition of the bleeding tendency in factor XI-deficient kindreds-a clinical and laboratory study. Thromb Haemost 73: 194-202.

11. Guéguen P, Galinat H, Blouch MT, Bridey F, Duchemin J, et al. (2012) Biological determinants of bleeding in patients with heterouzygous factor XI deficiency. Br J Haematol 156: 245-251.

12. Imanaka $\mathrm{Y}$, Lal K, Nishimura T, Bolton-Maggs PH, Tuddenham EG, et al. (1995) Identification of two novel mutations in non-Jewish factor XI deficiency. Br J Haematol 90: 916-920. 
Citation: Arabi A, Chekkal M, Charef L, Bouchama S, Mehded S, et al. (2015) Factor XI Deficiency: First Case Described in Algeria. J Blood Disord Transfus S5: S5-004. doi:10.4172/2155-9864.1000S5-004

Page 3 of 3

13. Imanaka $\mathrm{Y}, \mathrm{Lal} \mathrm{K}$, Nishimura $\mathrm{T}$, Bolton-Maggs $\mathrm{PH}$, Tuddenham EG, et al. (1995) Identification of two novel mutations in non-Jewish factor XI deficiency. Br J Haematol 90: 916-920.

14. Alhaq A, Mitchell M, Sethi M, Rahman S, Flynn G, et al. (1999) Identification of a novel mutation in a non-Jewish factor XI deficient kindred. Br J Haematol 104: 44-49.

15. Quélin F, Trossaërt M, Sigaud M, Mazancourt PD, Fressinaud E (2004) Molecular basis of severe factor XI deficiency in seven families from the west of France. Seven novel mutations, including an ancient Q88X mutation. J Thromb Haemost 2: 71-76.

16. Seligsohn U (2009) Factor XI deficiency in humans. J Thromb Haemost 7 Suppl 1: 84-87. 